\title{
SIPHONOSOMA CUMANENSE AND S. EDULE (SIPUNCULA) : A REEVALUATION OF THEIR SEPARATE STATUS
}

\section{AUTHOR(S):}

Cutler, Edward B.; Cutler, Norma J.; Nishikawa, Teruaki

\section{CITATION:}

Cutler, Edward B.... [et al]. SIPHONOSOMA CUMANENSE AND S. EDULE (SIPUNCULA) : A REEVALUATION OF THEIR SEPARATE STATUS. PUBLICATIONS OF THE SETO MARINE BIOLOGICAL LABORATORY 1983, 27(4-6): 265-267

\section{ISSUE DATE:}

1983-01-31

URL:

http://hdl.handle.net/2433/176054

RIGHT: 


\title{
SIPHONOSOMA CUMANENSE AND S. EDULE (SIPUNCULA): A REEVALUATION OF THEIR SEPARATE STATUS
}

\author{
Edward B. GUTLER, Norma J. GUTLER \\ Utica College of Syracuse University, Utica, New York 13502, U.S.A. \\ and \\ Teruaki NISHIKAWA \\ Biological Laboratory, College of General Education, \\ Nagoya University, Nagoya 464, Japan \\ With Text-figure 1
}

\begin{abstract}
Two species of the sipunculan genus Siphonosoma ( $S$. cumanense and $S$. edule) are determined to be conspecific. The determination rests largely on an analysis of a large series of individuals in which it is shown that as the animal increases in total size the introvert becomes proportionately shorter.
\end{abstract}

The two species Siphonosoma cumanense and $S$. edule have been the source of concern for a number of years. Stephen and Edmonds (1972: 47-49, 53) discuss the relationship between them and point to a similar concern of Sluiter (1886: 484). They acknowledge that the two are very close to one another and add, "Although it is possible that the two species are the same, we have hesitated to regard them as such at present." The alleged difference lies only in the ratio of the introvert to trunk length. S. edule has been described with a relatively short introvert (1/8$1 / 14$ of the trunk) while $S$. cumanense has a longer introvert (1/3-1/7). It must be remembered that these ratios have been measured on preserved specimens - preserved in a variety of fixatives and in a variety of relaxation states. When one observes living specimens in the field and the laboratory, it is obvious that the introvert is under voluntary muscular control so that its dimensions are constantly changing. To a lesser degree the same can be said for the trunk.

Stephen and Edmonds (1972: 53) also state, "What we have not been able to do is to examine a reasonably large sample of specimens from one locality which would enable one to decide whether the difference of length of the introvert are inter- or intra-specific." In Cutler and Cutler (1979: 946-949) such an analysis was performed on a population of worms from Tulear, Malagasy Republic. The data available at that time were such that we were able to place $S$. carolinense into synonomy with $S$. cumanense (it being at the small end of the continuum with long introverts) but with respect to $S$. edule could only state: "Extrapolating from the 


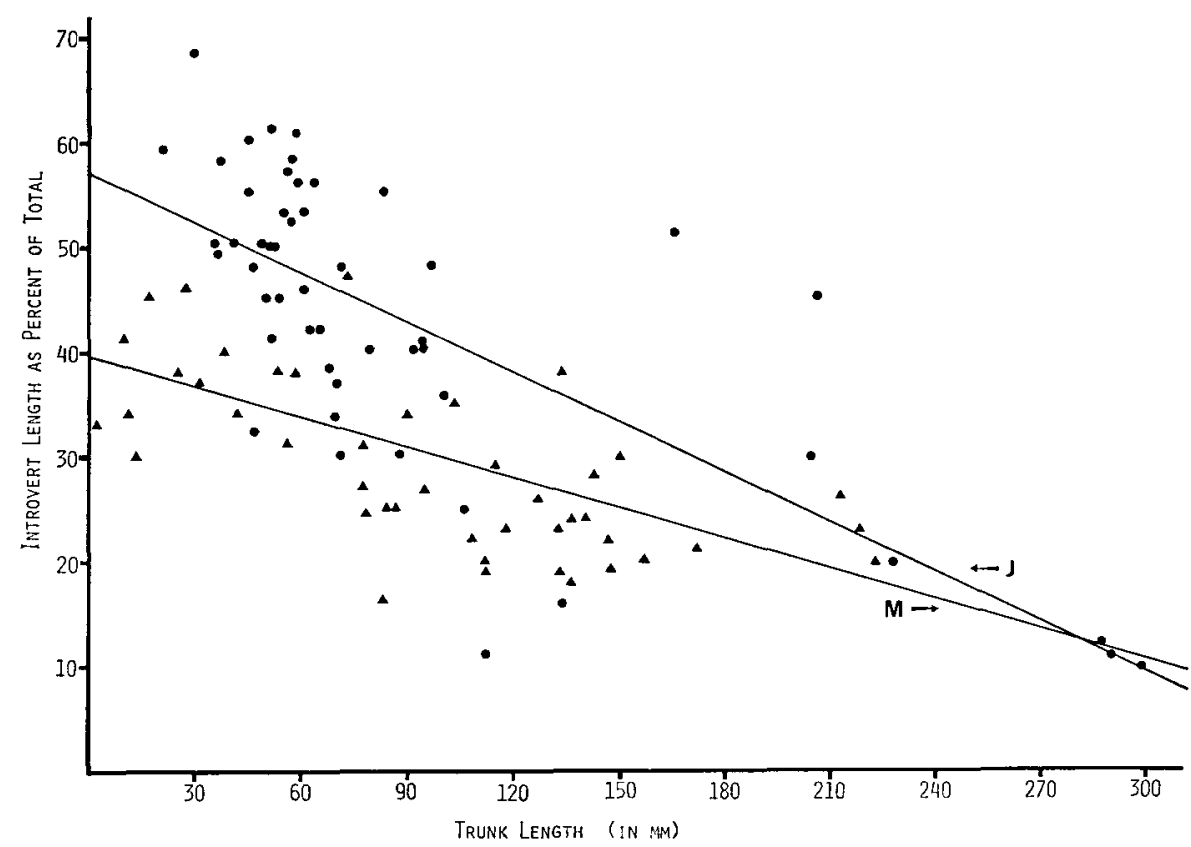

Fig. 1. Siphonosoma cumanense introvert length - an example of allometric growth. Circles are Japanese population, triangles are Malagasian population. The lines represent a simple linear regression $(Y=a+b x)$ for each population. The Japanese worms were narcotized prior to fixation, the Malagasian worms were not; this results in different slopes: $\mathrm{J}: \mathrm{a}=$ $56.7, \mathrm{~b}=-0.16 ; \mathrm{M}: \mathrm{a}=38.4, \mathrm{~b}=-0.13$.

data shown in fig. 1, it is possible that large $S$. cumanense (over $250 \mathrm{~mm}$ trunk) would have an introvert small enough to approach the $7-11 \%$ range reported for $S$. edule. The unanswered question then becomes: are $S$. edule only very large $S$. cumanense or $S$. cumanense with unusually short introverts?"

Our measurements were based on smaller worms but in recent Japanese collections, large worms are present and we have made additional measurements (Fig. 1). It is now clear to us that as these worms increase in size, the rate of growth of the introvert is slower than the trunk and that those few larger individuals, when seen in isolation from a population have erroneously been considered a distinct species. During a recent visit to the Royal Scottish Museum, Edinburgh, we measured five specimens identified by A.C. Stephen as S. edule from Mauritius (unpublished). The introverts of these varied in length form $23-34 \%$ of the total - well within the values shown in Fig. 1. The type material of $S$. edule cannot be located.

We hereby consider $S$. cumanense and $S$. edule to be conspecific. As $S$. edule is the older name, a strict application of the Law of Priority would require that $S$. cumanense be reduced to a junior synonym. However, because the name $S$. cumanense has been widely used by many biologists over the last 75 years (and $S$. edule only twice) we are petitioning the International Commission of Zoological Nomenclature to conserve the more widely used and familiar name, $S$. cumanense, for this taxon. 


\section{Synonymy}

For that prior to 1965 see Stephen and Edmonds, 1972: 46-53.

Siphonosoma carolinense: Fischer, 1928: 138-140; Stephen \& Edmonds, 1972: 44-46.

Siphonosoma cumanense: Murina, 1967: 1338; Christie \& Cutler, 1974: 109; Halder, 1975: 57; Cutler, 1977: 138; Gibbs, 1978: 85; Cutler \& Cutler, 1979: 946-949; Edmonds, 1980: 14-15.

Siphonosoma edule: Halder, 1975: 58.

Siphonosoma novaepommeraniae: Wesenberg-Lund, 1959: 55-58.

\section{Acknowledgments}

The worms from Tulear, Malagasy Republic were provided by B. Thomassin, Centre d'Oceanographie, Marseille, France. The Japanese worms were collected at the Sesoko Marine Biology Laboratory, University of the Ryukyus, Okinawa, through the courtesy of Dr. K. Yamazato to whom we are indebted. This work was made possible by grants from the U.S. National Science Foundation (INT 78-14554 and DEB 80-11121) to E.B.C.

\section{REFERENCES}

Christie, N.D. and E.B. Cutler. 1974. New Distribution records for two species of Siphonosoma (Sipuncula) collected using a diver-operated suction sampler. Trans. roy. Soc. S. Afr. 41 (2): 109110.

Cutler, E.B. 1977. The bathyal and abyssal Sipuncula. Galathea Rep. 14: 135-156.

Cutler, E.B. and N.J. Cutler. 1979. Madagascar and Indian Ocean Sipuncula. Bull. Mus. natn. Hist. nat., Paris, $4^{\text {e }}$ ser. 1 , sect. A, $n^{\circ} 4: 941-990$.

Edmonds, S.J. 1980. A revision of the systematics of Australian sipunculans (Sipuncula). Rec. S. Aust. Mus. 18 (1): 1-74.

Fischer, W. 1928. 11. Uber zwei neue Siphonosoma-Arten der Wurtt. Naturalien-Sammlung zu Stuttgart. Zool. Anz. 76: 138-143.

Gibbs, P.E. 1978. Macrofauna of the intertidal sand flats on low wooded islands, northern Great Barrier Reef. Phil. Trans. R. Soc. Lond. B 284: 81-97.

Halder, B.P. 1975. Sipuncula of the Indian Ocean in the collection of the Zoological Survey of India. In: Rice, M.E. and M. Todorovic (eds.) Proc. internat. Symp. Biol. Sipuncula and Echiura 1: 51-92. Naunco Delo Press. Belgrade.

Murina, V.V. 1967. Report on the sipunculid worms from the sublittoral zone of Cuba and Mexican Gulf. Zool. Zhur. 54 (9): 1329-1339.

Sluiter, C. 1886. Beitrage zu der kenntnis der Gephyreen aus dem Malayischen Archipel. Nat. Tijdschrift Neder.-Indie 45: 472-517.

Stephen, A.C. and S.J. Edmonds. 1972. The phyla Sipuncula and Echiura. Trustees of Brit. Mus. (Nat. Hist.) London, $528 \mathrm{pp}$.

Wesenberg-Lund, E. 1959. Sipunculoidac and Echiuroidea from tropical West Africa. Atlantide Rep. 5: 177-210. 